\title{
CZY NOWA KODYFIKACJA PRAWA CYWILNEGO JEST POTRZEBNA W CZASIE KRYZYSU PRAWA?
}

\section{WPROWADZENIE}

Niemal dwieście lat temu Friedrich Carl von Savigny pisał: obecny czas nie jest powołany do kodyfikacji. Pełni entuzjazmu zwolennicy kodyfikacji uzależniają jej pomyślny wynik od samych usilnych starań, co jednak nie wystarcza. Istotne jest to, by nauka prawa wypełniała to, co do niej należy i czego tylko ona może dokonać. Jeśli bowiem rozważymy faktyczny stan rzeczy, to spostrzeżemy, że jesteśmy uwikłani w niezmierzonej masie pojęć i poglądów prawnych gromadzonych z pokolenia na pokolenie. W obecnej sytuacji nie władamy tym materiałem i nie panujemy nad nim. Jednocześnie na porządku dziennym postawiona jest kwestia lepszego unormowania prawa cywilnego. Powstaja projekty zwiazane z zakorzenionym poglądem na temat tworzenia wszelkiego prawa pozytywnego. Słyszy się także skargi na wielkie zróżnicowanie praw krajowych. Na tym zróżnicowaniu rzekomo cierpi wymiar sprawiedliwości i choć mówi się, że obrót prawny jest utrudniony, to nie przemawia za tym żadne doświadczenie. Prawdziwe przyczyny tych skarg sa przeważnie inne i sprowadzają się do nieopisanego nacisku, jaki już od dawna wywiera w Europie abstrakcyjna idea uniformizmu we wszystkich kierunkach. Najbardziej bowiem zgubna jest łatwa i arbitralna odmiana prawa cywilnego, która choćby nawet była czymś pozytywnym pod względem prostoty i wygody, to jednak zysk taki nie mógłby zrównoważyć następstw ujemnych ${ }^{1}$.

Pomimo upływu lat i odmiennego kontekstu powyższe zapatrywania zdumiewająco pasują do dzisiejszej refleksji nad przyszłością nauki prawa w Polsce, zwłaszcza w dobie obecnych zamiarów kodyfikacyjnych. Opinie te wpisuja się także w przygnębiająca, ale moim zdaniem trafną diagnozę aktualnego stanu rodzimej cywilistyki, przedstawioną niedawno na łamach „Państwa i Prawa" przez Andrzeja Mączyńskiego². Co zastanawiające, autor nie zaproponował remedium na coraz wyraźniejszy kryzys, dotykający nie tylko naukę, lecz także judykaturę i legislatywę. Niewątpliwie jednak jego obserwacje sto-

${ }^{1}$ Por. F. C. von Savigny, O powołaniu naszych czasów do ustawodawstwa i nauki prawa, tłum. K. Opałek, PWN, Warszawa 1964.

2 A. Mączyński, Uwagi o stanie nauki polskiego prawa cywilnego, „Państwo i Prawo” 2011, z. 6, s. 3 i n. 
ją w sprzeczności z optymizmem kodyfikatorów, proponujacych na najbliższe lata „terapię zajęciową," polegającą na pracach nad nową ustawą.

Nurt kodyfikacyjny absorbuje energię i środki. Z jednej strony jest to szansa dla osób zasiadających w komisjach do integracji i wymiany poglądów, z drugiej - należałoby zadać pytanie, czy kodyfikując, rzeczywiście wykonamy krok w dobrą stronę.

\section{POD BATUTĄ USTAWODAWCY}

Polski świat prawniczy podporządkowany pandektystycznemu kodeksowi cywilnemu żyje w monofonii, w której wiodący ton nadaje głos ustawodawcy monopolisty na tym obszarze aktywności twórczej. Korzystając z tej metafory, można dostrzec, że jeszcze parę dekad temu kompozycje prawodawcy miały logiczną budowę formalną i choć charakteryzowały się nieskomplikowaną linią melodyczna, to mogły liczyć na wysublimowany akompaniament nauki i orzecznictwa. Dawne dzieła wpadały w ucho i były odpowiednio zaaranżowane do potrzeb ówczesnego audytorium. Po pewnym czasie ustawodawca uwierzył jednak w swój geniusz, czując potrzebę uszczęśliwienia słuchaczy kolejnymi utworami. W efekcie dzieła wydłużyły się ze zwyczajowych trzech minut do kilkunastu, niektóre motywy zaczęły się powtarzać, pojawiły się oczywiste niedoróbki i zapętlenia. Wtedy kompozytorowi przyszedł z pomoca wybitny przedstawiciel europejskiego nurtu monofonii, na którym rodzimy twórca zaczął się wzorować. Skutkiem tego od paru lat partia akompaniamentu jest coraz uboższa, obecnie prawie niesłyszalna. Tymczasem na rynku muzycznym pojawia się rocznie nawet kilkanaście płyt, a ich zakup jest obligatoryjny dla każdego, kto chce się uważać za melomana. Aktualnie soliści nie nadążaja z odgrywaniem powstających utworów, natomiast rola akompaniatorów sprowadza się do prostych czynności, wymagających jedynie opanowania podstaw gry na instrumencie. Muzykolodzy podzielili się na grupy - część dalej prowadzi badania nad powstającymi utworami, inni szukaja punktów odniesienia w muzyce zagranicznej lub dawnej, jeszcze inni wraz z solistami postanowili wpłynąć na kompozytora i zaoferowali mu pomoc przy stworzeniu opus magnum. Planowane działo stanowić ma „nowe otwarcie”, po którym zaktualizowane mają zostać podręczniki muzykologii, otworzy się szansa na prowadzenie badań nad neomonofonia, a na wypadek gdyby pojawiły się nieznane źródła dźwięku, grupa asystentów będzie w gotowości do dokonania transpozycji na nowe instrumentarium. W niedługim czasie nazwisko kompozytora znów ma okryć się sława, a społeczeństwu w życiu codziennym towarzyszyć będa te - dobrze im przecież znane - melodie, w które ludzie zasłuchają się z tym samym rozrzewnieniem, co pięćdziesiąt lat temu. Muzyka złagodzi obyczaje i uczyni świat piękniejszym.

Czy jednak publiczność nie odwróci się w końcu od takiej sztuki? A może nadszedł już czas, by zerwać z niektórymi dogmatami i otworzyć się na nowy repertuar? 


\section{NOWY KODEKS ALBO...?}

W myśleniu o przyszłości wypada przede wszystkim podać w wątpliwość tezę, że lepsze prawo przyjdzie od ustawodawcy. Patrząc na obecny poziom parlamentaryzmu, można zauważyć, że nawet przedłożenie idealnego projektu nie daje gwarancji uchwalenia dobrego kodeksu, gdyż przygotowany materiał może zostać poddany takim obróbkom, które zniweczą pracę kodyfikatorów. Poza tym pożądany „negocjacyjny model tworzenia prawa” ${ }^{3}$ dziś coraz bardziej przekształca się w monolog ustawodawcy.

Zbigniew Radwański wskazał, że: „Komisja Kodyfikacyjna Prawa Cywilnego, podejmując decyzję o zastosowaniu w projektowanym kodeksie cywilnym $\mathrm{w}$ zasadzie pandektowego systemu podziału z charakterystycznym dla niego wyróżnieniem części ogólnej, kierowała się przede wszystkim ogólnym założeniem, że kodeks ten powinien stanowić kontynuację polskiej myśli cywilistycznej, a w konsekwencji nie wprowadzać zmian dla samych zmian, bez oczywistej potrzeby". Wśród głównych przyczyn konieczności podjęcia prac legislacyjnych wskazuje się na zjawisko dekodyfikacji ${ }^{5}$, polegajace na rozmnożeniu regulacji szczegółowych, osłabiających centralną pozycję kodeksu w systemie oraz pozbawiających ów system cech spójności ${ }^{6}$. Fryderyk Zoll słusznie zauważył, że taki stan rzeczy wynika ze „[...] sposobu stanowienia prawa, zwłaszcza w warunkach demokratycznych”. Następuje bowiem „,...] daleko idaca specjalizacja, prowadząca do tego, że osoby tworzące prawo starają się przedstawić możliwie kompletne regulacje danej dziedziny. Nie ogarniając całego systemu prawa, boją się proponować rozwiązania mające współgrać z bardziej ogólnymi regułami, nie będąc w stanie określić ani jakie to są reguły, ani jakie będą wszystkie skutki zastosowania reguł bardziej ogólnych, a więc w pełni przystających do przedmiotu danej regulacji. Dla bezpieczeństwa wola zatem oni stworzyć własne reguły, nawet stanowiące po części superfluum [...]. Takie prawo jest także łatwiejsze w stosowaniu, ponieważ nie wymaga od użytkownika całościowej wiedzy prawniczej i znajomości wszelkich powiązań i kontekstów".

Skoro dostrzegamy, że dekodyfikacja bynajmniej nie omija polskiego porządku prawnego - czy jedynym środkiem do jej przezwyciężenia jest... kodyfikacja?

${ }^{3}$ Por. zwłaszcza A. Bierć, Racjonalna procedura prawodawcza jako podstawa dobrego prawa, w: W. Czapliński (red.), Prawo w XXI wieku. Księga pamiatkowa 50-lecia INP PAN, Scholar, Warszawa 2006, s. 92.

${ }^{4}$ Z. Radwański, Problem struktury przyszłego kodeksu cywilnego, „Transformacje Prawa Prywatnego" 2010, z. 4, s. 17.

${ }^{5}$ Dorobek europejskiej doktryny w zakresie prób uchwycenia zjawiska dekodyfikacji syntetycznie przedstawiono w: W. Dajczak, F. Longchamps de Bérier, Prawo rzymskie w czasach dekodyfikacji, „Forum Prawnicze” 2012, nr 2 (10), s. 9-11.

${ }^{6}$ Por. T. Giaro, Wyktadnia bez kodeksu. Uwagi historyczne o normatywności interpretacji prawniczej, w: P. Winczorek (red.), Teoria i praktyka wyktadni prawa. Materiały konferencji naukowej WPiA UW odbytej w dniu 27.02.2004 r., Liber, Warszawa 2005, s. 16.

7 F. Zoll, Problem struktury przyszłego kodeksu cywilnego, w: M. Kosek, J. Słyk (red.), W trosce o rodzinę. Księga pamiatkowa Prof. Wandy Stojanowskiej, C. H. Beck, Warszawa 2008, s. 648.

8 Ibidem. 
W ostatnich latach wiele się wydarzyło. W 2006 r. Komisja Kodyfikacyjna Prawa Cywilnego opublikowała Zieloną księgę o znamiennym podtytule Optymalna wizja Kodeksu cywilnego w Rzeczypospolitej Polskiej ${ }^{9}$. Dwa lata później przedłożono pod dyskusję projekt księgi pierwszej nowego kodeksu cywilnego wraz z uzasadnieniem ${ }^{10}$. Działania kodyfikacyjne napotkały stanowcze veto judykatury ${ }^{11}$, sceptyczna wobec zmian jest także część przedstawicieli doktryny $^{12}$. Mimo tej krytyki prace nad przygotowaniem kompletnego projektu nowego kodeksu są kontynuowane.

Wydaje się, że ostatnio dyskusja o przyszłości sprowadzona została do dylematu: kodyfikować czy nie. Jednocześnie nie przedstawiono żadnego istotnego alternatywnego planu działania. W ten sposób polska cywilistyka stoi dzisiaj przed mało fortunnym dylematem: nowy kodeks albo inercja. Czy jednak nie powinniśmy postulować rozwiązań bardziej odważnych, zwłaszcza że dekodyfikacja jawi się jedynie jako wierzchołek góry lodowej problemów, z jakimi boryka się współczesne prawo cywilne?

\section{MILCZĄCE UNIWERSYTETY}

Coraz bardziej uwidacznia się kryzys uczelni, które po latach inwestowania w dydaktykę nastawioną na masowego studenta poważnie zatraciły swoją naukową żywotność. Finezję dobija dziś system punktowy nastawiony na ilość, a nie na jakość publikacji. W tej atmosferze można powątpiewać, czy rzeczywiście mamy do czynienia z poprzedzającą kodyfikację „wielką mobilizacja polskiej nauki prawa prywatnego"13.

Przyjrzeć wypada się nauczaniu prawa cywilnego. Biorąc pod uwagę dydaktyczną użyteczność systematyki pandektowej, nie dziwi, że większość podręczników prawa cywilnego powiela kodeksowy model katalogowania materii $^{14}$ i staje się tym samym przejrzystym i zarozumiałym dla studenta przewodnikiem po ustawie. Pamiętać jednak należy, że kodeks jest to tylko pewna konwencja, podobna zresztą do tej, którą posługuje się astronomia, porządkując niebo według gwiazdozbiorów. Obiekty tworzące określoną konstelację są przecież oddalone od siebie o miliony lat świetlnych, a ich przynależność do danego gwiazdozbioru jest uzasadniona obserwacja nieba (li tylko) z naszej planety. Dlatego też ucząc studentów, należy unikać sytuacji, w której

${ }^{9}$ Komisja Kodyfikacyjna Prawa Cywilnego działająca przy Ministrze Sprawiedliwości, Zielona Księga. Optymalna wizja Kodeksu cywilnego w Rzeczypospolitej Polskiej, Z. Radwański (red.), Oficyna Wydawnicza MS, Warszawa 2006.

${ }^{10}$ Komisja Kodyfikacyjna Prawa Cywilnego działająca przy Ministrze Sprawiedliwości, Księga pierwsza Kodeksu cywilnego. Projekt z uzasadnieniem, Oficyna Wydawnicza MS, Warszawa 2008.

${ }^{11}$ Por. Projekt Kodeksu cywilnego Ksiega pierwsza. Sprawozdanie z dyskusji przeprowadzonej w Izbie Cywilnej Sadu Najwyższego, „Przegląd Sądowy” 2010, nr 2, s. 104-123.

12 Tu zwłaszcza: A. Mączyński, op. cit., s. 17.

${ }^{13}$ Por. F. Zoll, op. cit., s. 635.

${ }^{14}$ Wyjątkiem jest tu m.in. wydany niedawno podręcznik Andrzeja Biercia - A. Bierć, Zarys prawa prywatnego. Część ogólna, Wolters Kluwer business, Warszawa 2012. 
mogliby oni choćby przez chwilę nabrać przekonania o heliocentrycznej wizji świata - z kodeksem cywilnym jako dominanta, Wszechświatem jako sklepieniem niebieskim i obcymi systemami prawnymi jako odległymi galaktykami widocznymi tylko wtedy, gdy zajdzie Słońce.

Nauczanie prawa cywilnego ściśle według schematu budowy kodeksu tłumaczy po części przyjęta formuła testów na aplikację, wymagająca od kandydatów jedynie pamięciowego opanowania wskazanych ustaw. Godną ubolewania jest tendencja, by kryterium „zdawalności na aplikację” podnosić do rangi wyznacznika poziomu nauczania wydziałów prawa ${ }^{15}$. Myślenie tymi kategoriami doprowadzić może do tego, że synonimem akademickiego sukcesu stanie się uczelnia, która na pierwszych latach uczy mnemotechnik, a w dalszych mantrycznego przyswajania treści kodeksów. Jeśli dostrzega się te zagrożenia, coraz mniej dziwią głosy części przedstawicieli doktryny, że „w Polsce nie ma wydziałów prawa, studenci kształcą się na "wydziałach przepisów prawa«"16.

Zorientowanie refleksji nad prawem na samej tylko egzegezie ustawy uwidacznia się także w prowadzonych badaniach naukowych, w których teoretyczne rozważania cywilistów często sprowadzają się jedynie do przedstawienia, jak uregulowano dany problem, a nie jak należy go uregulować. Obserwowalny renesans wygodnej metody formalno-dogmatycznej prowadzi do tego, że teoretycy coraz częściej zamiast rozwiązywać problemy obrotu prawnego, rozwiąuja problemy prawników. Już ponad pół wieku temu Stanisław Ehrlich wskazywał na niebezpieczeństwo pochłonięcia nauki przez tzw. jurysprudencję pojęć, będącą swego rodzaju „żonglerką konstrukcjami”, prowadzącą na tory ciasnego praktycyzmu oraz izolowania się nie tylko od innych gałęzi nauki, ale nawet poszczególnych dyscyplin prawnych ${ }^{17}$. Dziś wszystkie te zagrożenia są jak najbardziej realne, i objawiają się trudnymi do zbagatelizowania symptomami, jak brak interdyscyplinarności badań, ich ahistoryczność (względnie zamieszczanie $\mathrm{w}$ pracach quasi-historycznych wstępów), a także nadużywanie przymiotnika „prawnoporównawczy” dla określania także tych opracowań, w których jedynie zestawiono polskie przepisy z tłumaczeniami ich potencjalnych zagranicznych odpowiedników, bez analizy funkcjonowania norm w poszczególnych systemach.

W efekcie odnieść można wrażenie, że powoli stajemy się samotną wyspa na mapie światowej cywilistyki. Nie dość, że posługujemy się niełatwym do opanowania dla obcokrajowców językiem, to jeszcze stworzyliśmy prawniczy metajęzyk, zrozumiały tylko dla wąskiej kasty, strzegącej swojego know-how, będącego już nie tyle sztuka, ile zwykłą umiejętnością odnajdywania się w nawarstwiającym się gąszczu przepisów ${ }^{18}$. Prawnik cywilista potrafi więc znakomicie poruszać się po obszarze zakreślonym przez prawodawcę: systematyzuje

15 Krytycznie w tym temacie: M. Andrzejewski, Wyniki testów nie świadczq o poziomie ksztatcenia, „Rzeczpospolita” z 18 lutego 2010 r.

${ }_{16}$ Prawo i niesprawiedliwość, wywiad z prof. Tomaszem Tadeuszem Koncewiczem, „Gazeta Wyborcza - Magazyn Świąteczny” z 8-9 września 2012 r., s. 18-19.

17 S. Ehrlich, O metodzie formalno-dogmatycznej, „Państwo i Prawo” 1955, z. 3, s. 377-378.

${ }^{18} \mathrm{~W}$ podobnym duchu E. Łętowska, Znajomość treści prawa czy biegłość w metodach jego poznawania, w: A. Janik (red.), Studia i rozprawy. Księga dedykowana profesorowi Andrzejowi Całusowi, Oficyna Wydawnicza SGH, Warszawa 2009, s. 90. 
przepisy, przeprowadza ich opis klasyfikacyjny z punktu widzenia wewnętrznych technicznoprawnych związków i różnic, określa reguły wykładni. Jest to wyłączny teren jurysty, który sobie zagospodarował, dopuszczając do niego tylko nielicznych „nieprawników”, najlepiej tych, którzy nie będą mu zakłócać wygodnej wizji świata. W tej atmosferze pogłębia się konserwatyzm metodologiczny, skutkujacy choćby ucinaniem śmiałych pomysłów - o ile takowe się pojawiaja - arbitralnym i wygodnym (bo niesprawdzalnym) argumentem o tym, że realizacja danego postulatu może być „groźna dla pewności obrotu prawnego".

W efekcie polska cywilistyka nie budzi większego zainteresowania badaczy z zagranicy, i to pomimo tego, że jeszcze 80 lat temu byliśmy w awangardzie, tworząc - wyprzedzający swoją epokę - synkretyczny Kodeks zobowiązań, któremu zresztą w znacznej mierze obowiązujący dziś Kodeks cywilny zawdzięcza swoją żywotność. Umiędzynarodowienie rodzimej cywilistyki wygląda słabo na tle innych nauk społecznych, co uwidacznia się zwłaszcza w dobie raczkującego systemu grantowego, opartego na systemie cytowań. Czy wszystkie słabości własnej dziedziny da się wytłumaczyć „,wyjątkową lokalnością”?

\section{FABRYKI ORZECZEŃ}

Niepokoi brak zaufania ustawodawcy do judykatury, objawiający się ciagłym brnięciem w kazuistykę, czego najlepszym przykładem jest wydawanie aktów prawnych o niemal dwustustronnicowej objętości. W ten sposób sędziom pozostawia się coraz mniejsze pole interpretacji. Zresztą trudno oczekiwać kreatywności zapadających orzeczeń, biorąc pod uwagę obłożenie sądów, ogólne niedofinansowanie wydziałów cywilnych, a także uzależnienie Temidy od ministerialnych wskaźników.

Od sędziego wymaga się obecnie przede wszystkim szybkich rozstrzygnięć, choć przydziela się mu ilość spraw niewspółmierną do czasu potrzebnego na wydanie przemyślanych decyzji. Jednakże samo zbudowanie sentencji oraz jej uzasadnienie to tylko finalny efekt procesu orzekania, w czasie którego sędzia odpowiedzialny jest również za podejmowanie niezliczonej ilości sformalizowanych i czasochłonnych czynności materialno-technicznych, choć w zachodnich systemach wykonuje je sekretarz, względnie referendarz.

Galopujaca legislacja w obszarze prawa prywatnego niebezpiecznie zmierza w kierunku sprowadzenia sędziego do roli „lepszego urzędnika”, mającego podążać według ściśle wytyczonych instrukcji. Wydaje się więc, że to już naprawdę ostatni dzwonek, by zaapelować o to, by sędziom po prostu zaufać.

Powyższa refleksja jest trudna do pogodzenia z idea, by zawód sędziego był ukoronowaniem zawodów prawniczych. W Polsce realizację tego postulatu rozpoczęto nie od stworzenia odpowiednich warunków, lecz podniesienia wieku nominacji oraz wdrożenia aplikantów sądowych w nowy system formacji, wymagający czasowego przeniesienia swojego centrum życiowego na południe kraju. 
Gdy zestawia się model kształcenia przyszłych sędziów z ograniczeniami wynikajacymi z nadzoru oraz ustawową kazuistyka, wzrasta poczucie zagrożenia, że już niedługo niezawisłość judykatury stać się może iluzją. Pole wykładni zostało bowiem w ostatnich latach istotnie ograniczone, nadto dla sędziego każdy dłuższy namysł nad sprawą oraz nieszablonowa decyzja znajdzie swoje - najczęściej negatywne - odzwierciedlenie w ministerialnych tabelach, majacych niebagatelne znaczenie przy awansach.

Punktem odniesienia koniecznych zmian może być model niemiecki, w którym nominacja sędziowska postrzegana jest jako jedna z najwyższych nobilitacji dla prawnika. Prestiż idzie tam w parze nie tylko z odpowiednim wynagrodzeniem, lecz także rzeczywistą gwarancją niezawisłości, podbudowana większym niż w Polsce komfortem pracy. W takich warunkach nie dziwi, że pomimo podejmowania rozstrzygnięć w oparciu o pandektystyczny kodeks cywilny (Bürgerliches Gesetzbuch - BGB), orzecznictwo niemieckie wykształciło rodzaj twórczej wykładni, wykraczajacej poza brzmienie przepisu (richterliche Rechtsfortbildung) ${ }^{19}$.

W Polsce natomiast trójpodział władzy już niedługo stać się może mitem, skoro judykaturze już teraz de facto związano już ręce. Najwyraźniej u nas „[...] ciagle jeszcze nie ukształtował się pogląd, że prawotwórstwo sądowe spełnia funkcję pożyteczną"20. Najwyższa pora to zmienić.

\section{VI. ŚWIAT ZZA KODEKSOWEJ SZYBY - DWA PRZYKŁADY}

Mając na względzie wady obecnego modelu, nie jest łatwo żywić nadzieję na zmianę jakościowa, jaką przynieść miałby nowy kodeks. Wiele wskazuje na to, że prace kodyfikacyjne według wyżłobionej pół wieku temu koleiny moga posłużyć co najwyżej do utrzymaniu obecnego status quo. Optymizmem nie napawają ostatnie dokonane już oraz rozważane zmiany w Kodeksie cywilnym, czyniące aktualnym pytanie o to, czy rzeczywiście władamy materiałem, który chcielibyśmy uregulować. Tytułem przykładu wskazać można wprowadzenie przed dziesięcioma laty przepisu regulującego tzw. odpowiedzialność przedkontraktową (art. $72 \S 2$ k.c.) oraz prawne ujęcie problemu wyzysku (art. 388 k.c.).

Przepis art. $72 \S 2$ k.c. o następującej treści: „Strona, która rozpoczęła lub prowadziła negocjacje z naruszeniem dobrych obyczajów, w szczególności bez zamiaru zawarcia umowy, jest obowiązana do naprawienia szkody, jaka druga strona poniosła przez to, że liczyła na zawarcie umowy" dodano do Ko-

19 Szerzej na temat tego zjawiska por. T. Spyra, Granice wykładni prawa. Znaczenie językowe tekstu prawnego jako granica wyktadni, Wolters Kluwer, Warszawa 2006, s. 55-59 i 102-107. O sztandarowym „efekcie” sędziowskiego rozwijania prawa - instytucji culpa in contrahendo por. zwłaszcza R. Nirk, Culpa in contrahendo - eine richterliche Rechtsfortbildung - in der Rechtsprechung des Bundesgerichtshofes, w: W. Hefelmehl, H. C. Nipperdey (red.), Festschrift für Philipp Möhring, C. H. Beck, München 1965, s. 385-418.

${ }^{20}$ A. Stelmachowski, Problemy legislacji, w: A. Nowicka (red.), Prawo prywatne czasu przemian. Księga Pamiatkowa ku czci Profesora Stanistawa Sottysińskiego, Wydawnictwo Naukowe UAM, Poznań 2005, s. 110. 
deksu w ramach większej nowelizacji z 2003 r. ${ }^{21} \mathrm{Z}$ lakonicznego uzasadnienia projektu nie wynika nic poza tym, że ustawodawca a priori uznał, że rzeczony przepis winien znaleźć się w Kodeksie ${ }^{22}$. Nie wiadomo więc, czy ustawodawca brał pod uwagę doświadczenie innych państw, jakie rozważał warianty oraz na jakich mierzalnych danych lub innych zarejestrowanych sygnałach płynących od uczestników obrotu oparł swoją decyzję.

Tymczasem w systemie common law, podobnie jak w prawie rzymskim, przyjęto założenie, że sfera negocjacji jest - co do zasady - prawnie indyferentna, a granicą swobody rokowań są zachowania rażąco naganne, jak podstęp czy groźba. Ryzyko fiaska pertraktacji wpisuje się tym samym w codzienność uczestników obrotu, albowiem uznaje się, że rokowania to obszar ścierania się przeciwnych interesów, gdzie każda ze stron dba przede wszystkim o własną korzyśćc ${ }^{23}$.

Dużo bardziej bogate jest natomiast doświadczenie niemieckie, które ukazuje, jak na treść regulacji normatywnej wpłynać mogą konstrukcje doktrynalne. Po kilku dekadach obowiązywania BGB, aby wypełnić lukę wynikająca z fragmentaryczności niemieckich przepisów deliktowych, „odkryto na nowo” dziewiętnastowieczny pomysł Rudolfa von Jheringa, by przyznać negocjujacej stronie kontraktowa skarge ex culpa in contrahendo ${ }^{24}$. Z czasem zakres ochrony przedkontraktowej w Niemczech ulegał systematycznemu rozszerzaniu, co wespół z korzystnym dla powoda rozłożeniem ciężaru dowodu oraz długim terminem przedawnienia (30 lat) uczyniło z rzeczonej skargi „wielofunkcyjny instrument z niebezpiecznie szerokim polem zastosowania" ${ }^{25}$. W 2001 r. ramach reformy niemieckiego prawa zobowiązań (Schuldrechtmoderniesierung) ${ }^{26}$ skodyfikowano instytucję culpa in contrahendo ${ }^{27}$, co interpretować można jako nobilitację dorobku doktryny i orzecznictwa, których rozwiąania urosły niniejszym do rangi ustawowej. Dostrzegalna jest jednak także ta motywacja niemieckiego prawodawcy, by przez regulację pozytywną nadać odpowiedzialności przedkontraktowej real-

${ }^{21}$ Ustawa z 14 lutego 2003 r. o zmianie ustawy - Kodeks cywilny oraz niektórych innych ustaw (Dz. U. 2003, Nr 408, poz. 49), która weszła w życie 25 września 2003 r.

22 Por. uzasadnienie projektu rządowego z 2 lipca 2002 r., druk Sejmu RP, nr 666, s. 29. Na niebudzącą wówczas wątpliwości potrzebę wprowadzenia nowej regulacji w zakresie odpowiedzialności za culpa in contrahendo wskazuje Wojciech J. Kocot. Autor ten nie uzasadnia jednak swojego stanowiska. Por. W. Kocot, Odpowiedzialność przedkontraktowa, C. H. Beck, Warszawa 2013, s. 76.

${ }^{23}$ Szerzej por. E. A. Farnsworth, Precontractual Liability and Preliminary Agreements: Fair Dealing and Failed Negotiations, „Columbia Law Review” nr 87, 1987, s. 218 i n.; A. A. Machnicka, Przedkontraktowe porozumienia - umowa o negocjacje $i$ list intencyjny. Studium prawnoporównawcze, Wolters Kluwer, Kraków 2007, s. 31 i n.

${ }^{24}$ Szerzej por. T. Giaro, Culpa in contrahendo: eine Geschichte der Wiederentdeckungen, w: U. Falk, H. Mohnhaupt (red.), Das Bürgerliche Gesetzbuch und seine Richter. Zur Reaktion der Rechtsprechung auf die Kodifikation des deutschen Privatrechts (1986-1914), Vittotio Klostermann, Frankfurt am Main 2000, s. 112-154.

${ }^{25}$ D. Medicus, Grundwissen zum bürgerlichen Recht. Ein Basisbuch zu den Anspruchsgrundlagen, Carl Heymanns Verlag, Köln 1995, za: Ł. Korecki, Zasada dobrej wiary przy negocjowaniu umowy w prawie angielskim, francuskim i niemieckim, „Przegląd Prawniczy Uniwersytetu Warszawskiego" 2003, nr 3, s. 35.

${ }^{26}$ Ustawa o modernizacji prawa zobowiązań (Gesetz zur Modernisierung des Schuldrechts), „Bundesgesetzblatt” (BGB1) 2001, I, s. 3138.

27 Por. $§ 313$ BGB w nowym brzmieniu. 
ne kontury ${ }^{28}$ oraz doprowadzić do sytuacji, w której uczestnicy obrotu mogą się dowiedzieć o istnieniu instytucji culpa in contrahendo wprost z lektury przepisów BGB, a nie - jak to miało miejsce wcześniej - jedynie od swoich prawników.

W Polsce natomiast przez dziesięciolecia ukształtował się konsensus o deliktowym charakterze odpowiedzialności za tzw. winę w kontraktowaniu, będący konsekwencją oparcia systemu odpowiedzialności za czyny niedozwolone na ogólnej klauzuli ${ }^{29}$. Tym samym w rodzimym systemie ochrona kontrahenta na etapie formowania umowy jest relatywnie słaba, gdyż to na poszkodowanym spoczywać będzie - trudny do przeprowadzenia w tego typu sprawach ciężar dowodu. Taki stan rzeczy niekoniecznie jednak należy traktować jako mankament - uczestnicy obrotu mogą cenić sobie sytuację, w której system prawny daje im szeroka swobodę rokowań i reaguje tylko w istotnych przypadkach. Poza tym pertraktujacy kontrahenci zawsze moga już na tym etapie zawrzeć odpowiednie porozumienie, np. umowę o negocjacje.

Dekadę temu rodzimy ustawodawca uznał jednak, że regulacja odpowiedzialności przedkontraktowej wymaga korekty. Wprowadzenie nowego przepisu art. $72 \S 2$ k.c. nie stanowiło przełomu. Wszystko wskazuje na to, że regulacja ta „na wzór BGB” jedynie potwierdza powszechnie przyjmowany pogląd, iż przypadki określane mianem winy w kontraktowaniu stanowią rodzaj odpowiedzialności deliktowej ${ }^{30}$. W tej sytuacji najbardziej sensownym rozwiąaniem wydaje się przyjęcie, że art. $72 \S 2$ k.c. stanowi superfluum wobec art. 415 k.c. Część doktryny dała się jednak wciagnąć w swoistą „grę pojęć” - buduje na kanwie tejże niefortunnej nowelizacji nowe teorie sugerujące m.in. daleko idącą autonomiczność rzeczonego przepisu jako szczególnej regulacji odpowiedzialności opartej na bezprawności ${ }^{31}$. W efekcie wokół omawianego przepisu narastają kontrowersje natury dogmatycznej, skutkujące inflacją opracowań teoretycznych, gdy tymczasem przez 10 lat obowiązywania nowej regulacji naliczyć można zaledwie trzy (!) publikowane orzeczenia odnoszące się do roszczeń na opartych na art. 72 § 2 k.c. ${ }^{32}$ Tak niewielka ilość spraw trafiających do

${ }^{28} \mathrm{~W}$ ramach reformy istotnie skrócono także terminy przedawnienia roszczeń z tego tytułu: z 30 do 3 lat (por. $§ 195$ BGB w danym i nowym brzmieniu).

${ }_{29}$ Z rozważań na gruncie kodeksu zobowiązań por. J. Górski, Przygotowanie umowy w świetle kodeksu zobowiazań, Poznań 1938, s. 1-124. W odniesieniu do kodeksu cywilnego por. Z. Radwański, Umowy, w: Z. Radwański (red.), System prawa cywilnego, t. 3: Prawo zobowiazań - część ogólna, INP PAN i Zakład Narodowy im. Ossolińskich, Wrocław 1981, s. 408 i n. W orzecznictwie por. w szczególności: uzasadnienie uchwały Sądu Najwyższego z 28 września 1990 r., III CZP 33/90, OSNC 1991, nr 1, s. 3.

${ }^{30}$ Tak: A. Olejniczak, $Z$ problematyki culpae in contrahendo-uwagi o znaczeniu przepisu art. $72 \S 2$ KC, w: M. Zieliński (red.), W kręu teoretycznych i praktycznych aspektów prawoznawstwa. Księga pamiatkowa Prof. Bronisława Ziemianina, Szczecin 2005, s. 127-152.

${ }_{31}$ Por. zwłaszcza P. Machnikowski, Odpowiedzialność przedkontraktowa-jej podstawy, przestanki i funkcje, w: M. Pazdan et al. (red.), Europeizacja prawa prywatnego, t. 1, Wolters Kluwer, Warszawa 2008, s. 710; W. Kocot, op. cit., s. 155.

32 Są to: wyrok Sądu Apelacyjnego w Warszawie z 13 października 2008 r., I ACa 669/08, Lex, nr 795208; wyrok Sądu Apelacyjnego w Szczecinie z 31 października 2012 r., I ACa 446/12, Lex, nr 1237853; wyrok Sądu Apelacyjnego w Katowicach z 28 grudnia 2012 r., I ACa 689/12, Portal Orzeczeń Sądów Powszechnych, http://orzeczenia.ms.gov.pl. 
wyższych instancji jest zastanawiająca, aczkolwiek wobec braku badań empirycznych w tym zakresie przyczyny pozostaja głównie w sferze domysłów ${ }^{33}$.

Omawiany przykład pokazuje, że intuicyjne poprawianie prawa niesie ze sobą chaos związany z trudnością w odkodowaniu, co prawodawca w swoim monologu miał na myśli. Jest to także dobra ilustracja niebezpiecznej tendencji osłabienia spójności systemu przez wprowadzanie zbędnych regulacji szczegółowych. Sytuacji tej można byłoby uniknąć, gdyby w refleksji nad projektowanymi zmianami sięgnięto po argument historyczny, wnikliwiej przeanalizowano dorobek obcych systemów prawnych oraz podjęto choćby próbę przeprowadzenia szerszych badań nad rzeczywistymi problemami uczestników obrotu.

Sporo do życzenia pozostawia także doktrynalna refleksja nad problemem wyzysku, ujętym w Kodeksie cywilnym w art. 388 k.c. W rodzimej cywilistyce z zagadnieniem tym wiąże się długoletni już spór o to, czy jest to wada oświadczenia woli, czy też jeden z przykładów przekroczenia zasady swobody umów. Ma on jednak charakter czysto akademicki, skutkujący głównie odciagnięciem prawników od meritum, jakim winien być namysł nad tym, jak skutecznie przeciwdziałać wyzyskowi.

Tymczasem rzeczony przepis chroni pokrzywdzonego jedynie pozornie. Pozycja procesowa wyzyskanego jest bowiem dramatycznie słaba, skoro musi on:

a) w terminie dwóch lat od zawarcia umowy (art. $388 § 2$ k.c.);

b) wykazać swoje przymusowe położenie, niedołęstwo lub niedoświadczenie;

c) wykazać, że zachowanie wyzyskującego podpada pod ustawową przesłankę (,wyzyskując");

d) wykazać rażacca nieekwiwalentność świadczeń.

Nie potrzeba wielkiej empatii, by dostrzec, że trudno oczekiwać od osoby niedołężnej czy znajdującej się w przymusowym położeniu, by w krótkim terminie zawitym nie tylko zorientowała się co do niekorzystnej dyspozycji swoim majątkiem, lecz także była w stanie ponieść ryzyko (i koszty) związane z wystapieniem na drogę sądowa, gdzie udźwignąć będzie musiała ciężar wykazania wszystkich wymienionych w ustawie okoliczności. W tym kontekście nie dziwi niewielka ilość orzeczeń zapadłych na podstawie art. $388 \S 1$ k.c., niewspółmiernie mniejsza $\mathrm{w}$ stosunku do innych wad oświadczenia woli, tudzież przekroczeń zasady swobody umów. Wydaje się przy tym, że problem wyzysku znalazł się w błędnym kole: ze względu na niewielką liczbę sądowych rozstrzygnięć doktryna nie dostrzega problemu nieefektywności omawianego przepisu ani nie postuluje zmian, wobec czego legislatywa uznaje, że przepis

\footnotetext{
${ }^{33}$ Najbardziej prawdopodobne przyczyny moim zdaniem to: a) mała ilość spraw, w których wartość przedmiotu zaskarżenia przekracza $50000 \mathrm{zł} \mathrm{(art.} 398^{1} \S 1$ k.p.c.); b) wysokie ryzyko procesowe, związane z trudnością wykazania naganności zachowania drugiej strony wobec niewielkiej wysokości spodziewanego odszkodowania, ograniczonego do tzw. ujemnego interesu umownego; c) uznanie przez spora część uczestników obrotu, że zachowania, które nawet podpadałyby pod dyspozycję przepisu art. $72 \S 2$ k.c., w praktyce są akceptowalne i mieszczą się w ramach ryzyka negocjacyjnego.
} 
spełnia swoją funkcję. Czy oznacza to, że w Polsce zjawisko wyzysku nie istnieje, a prawo prywatne dostatecznie chroni słabsze jednostki?

Warto zauważyć, że gdyby przepis art. 388 k.c. usunać z kodeksu, wówczas pozycja pokrzywdzonego polepszyłaby się, albowiem punktem ciężkości sądowego dociekania nie byłoby to, czy powód wykazał wszystkie ustawowe przesłanki, lecz to czy i w jakim stopniu czynności prawna naruszała dobre obyczaje. Obecnie natomiast art. 388 k.c. jako norma szczegółowa osłabia oddziaływanie ogólnej reguły z art. 58 § 2 k.c., tym samym czyni z prawnej regulacji wyzysku pustą deklarację ustawodawcy.

Zasygnalizować również wypada, że omawiany przepis został niemal wprost przejęty z Kodeksu zobowiązań, w którym jego pierwowzór - art. 42 k.z. stanowił hybrydę rozwiązania niemieckiego (art. 138 II BGB), szwajcarskiego (art. 21 Obligationenrecht) oraz odnośnego przepisu z projektu francusko-włoskiego (art. 22) ${ }^{34}$. Upłynęło już chyba wystarczająco dużo czasu, by ówczesny eksperyment ustawodawczy poddać odpowiedniej rewizji, zwłaszcza biorac pod uwagę zmiany legislacyjne, jakie zaszły w ostatnich dekadach w Austrii ${ }^{35}$, czy też dostrzeżoną w doktrynie i orzecznictwie niemieckim nieefektywność przepisu $§ 138$ II BGB BG. $^{36}$.

Mając na względzie obecny kształt rodzimej regulacji, rozważać należałoby więc nie tyle kwestię ulokowania odnośnego przepisu oraz jego ewentualna treść, lecz także to, czy zasadne jest, by regulacja na wzór art. 388 § 1 k.c. w ogóle w kodeksie się znajdowała. Brak szerszej refleksji w tym zakresie widoczny jest w przedłożonym projekcie części ogólnej kodeksu cywilnego ${ }^{37}$ oraz publikowanych opracowaniach roboczych ${ }^{38}$. Podkreślić przy tym trzeba, że nie jest łatwo wyobrazić sobie wnikliwą dyskusję na temat prawnej regulacji wyzysku bez udziału przedstawicieli innych dyscyplin naukowych, zwłaszcza socjologów, ekonomistów, czy filozofów.

Powyższe dwa przykłady pokazuja, że ostatnio prawodawca podją się zbędnej chirurgicznej ingerencji w zdrową tkankę ogólnej klauzuli deliktowej,

${ }^{34}$ Por. Projekt kodeksu francusko-włoskiego zobowiązań $i$ umów. Tekst ostateczny przyjęty w Paryżu w październiku 1927 roku, tłum. J. Wasikowski, Warszawa 1928, s. 8.

${ }^{35}$ Por. przepis $§ 33$ zd. 6 ustawy o ochronie konsumentów z 8 marca 1979 r. (Konsumentenschutzgesetz - KSchG, Bundesgesetz vom 8. März 1979, mit dem Bestimmungen zum Schutz der Verbraucher, StF: BGBl. Nr. 140/1979 ze zm. ), zmieniajacy $§ 935$ austriackiego kodeksu cywilnego (ABGB) w ten sposób, że przepis § 934 przewidujący możliwość unieważnienia umowy z uwagi na „pokrzywdzenie powyżej połowy” (tzw. laesio enormis) przestał być regulacją de facto martwa, „odżywając” jako przepis semiimperatywny w stosunkach konsumenckich.

${ }^{36} \mathrm{O}$ ewolucji niemieckiego orzecznictwa oraz doktryny w tym zakresie por. zwłaszcza M. Stürner, Der Grundsatz der Verhältnismäßigkeit im Schuldvertragsrecht. Zur Dogmatik einer privatsimmanenten Begrenzung von vertraglichen Rechten und Pflichten, Mohr Siebeck, Tübingen 2010, s. 43-64.

${ }^{37}$ Por. art. 121 projektu księgi pierwszej kodeksu cywilnego oraz s. 132 uzasadnienia. W projekcie interesujący wydaje się przepis art. $121 \S 2$, mogący stanowić swego rodzaju wytrych pozwalający uwolnić się od dotychczasowego ujęcia wyzysku. Niewiele można jednak powiedzieć o motywach oraz roli, jaką ten przepis w założeniu miałby w założeniu kodyfikatorów odgrywać, gdyż uzasadnienie projektu jest w tym zakresie nader lakoniczne.

${ }_{38}$ R. Trzaskowski, Wady oświadczenia woli w perspektywie kodyfikacyjnej, „Studia Prawa Prywatnego" 2008, nr 3, s. 1-86. 
inne zaś realne zagrożenia (jak wyzysk) nie są przedmiotem regularnych badań ${ }^{39}$, choćby nawet profilaktycznych. Naszego prawa na pewno nie polepszy wybiórcze kopiowanie zachodnich rozwiąań, natomiast dalsze funkcjonowanie pod pandektystycznym kloszem może sprawic, że staniemy się głusi na istotne potrzeby obrotu prawnego.

\section{PLAN NAPRAWCZY, CZYLI REFLEKSJA NAD POWOŁANIEM NASZYCH CZASÓW}

Obecnie coraz bardziej realna staje się wizja, w której cywilistyka wciąż pochłonięta będzie sporami o brzmienie przepisów, rola orzecznictwa zaś ograniczy się do prostego wykonawstwa sztywnych instrukcji ustawodawcy. Symbioza legislatywy, orzecznictwa i doktryny stanie się więc mrzonka. Gdy judykatura popadnie w atrofię, pociąnie za sobą naukę, nie dając jej naturalnej pożywki do pracy twórczej. W ten sposób środowisko prawa prywatnego stanie się monokulturą prawodawcy.

Oczywiście planowany nowy kodeks cywilny może przywrócić należyta range akompaniamentu nauki i judykatury dla melodii granej przez ustawodawcę. Może, ale nie musi. Szansa na to jest niewielka. Kodyfikacja rozumiana jako aktualizacja, co prawda uporządkowałby do pewnego stopnia materię, byłoby to jednak rozwiązanie tylko na pewien czas przykrywające poważne problemy, z którymi i tak przyjdzie nam się zmierzyć. Z tego względu wypada w końcu opuścić cywilistyczną wieżę z kości słoniowej i uwolnić się od dogmatu o nieomylności kodeksu cywilnego, a w szczególności zaprzestać traktowania go jako świętości nadanej nam z góry, bez której nie potrafilibyśmy żyć.

Należy przy tym powiedzieć głośno, że dotychczasowa metoda regulacji wyczerpała się. Obecnie potrzebujemy nie kodyfikacji, lecz ruchu jej przeciwnego także z logicznego punktu widzenia: niekodyfikacji, która pozwoliłaby odejść od statycznej monofonii, wynikającej z podporządkowania nauki i sadów ustawodawcy, na rzecz dynamicznej polifonii źródeł prawa.

Odrzucając dawne przyzwyczajenia, winniśmy więc obrać kurs na system ruchomy, którego rdzeniem byłyby zasady prawne, doprecyzowywane przez orzecznictwo inspirowane poglądami doktryny. To właśnie zasady prawne ukazują sposób czynienia użytku z prawa oraz są egzemplifikacją podstawowych założeń, wartości i idei wynikających z całości systemu ${ }^{40}$. Możemy - i powinniśmy - spierać się o ich treść, określać pewne preferencje i wskazywać na punkty kolizyjne. Dyskusje na ten temat od wieków są solą prawoznawstwa. Natomiast kodeks (dzisiejszy, ewentualnie przyszły) - oczyszczony ze zbęd-

39 Pomijam tu dogmatyczne analizy art. 388 k.c. - w tym zakresie wyczerpująco zwłaszcza M. Gutowski, Wzruszalność czynności prawnej, C. H. Beck, Warszawa 2010, s. 152-180; P. Machnikowski, Wyzysk, w: System prawa prywatnego, t. 5: Prawo zobowiazań-część ogólna, red. E. Łętowska, C. H. Beck - Instytut Nauk Prawnych PAN, Warszawa 2006, s. 519-530.

${ }_{40}$ Por. zwłaszcza M. Safjan, Pojęcie $i$ funkcje zasad prawa prywatnego, w: A. Brzozowski, W. Kocot, K. Michałowska (red.), W kierunku europeizacji prawa prywatnego. Księga Pamiatkowa dedykowana Prof. Jerzemu Rajskiemu, C. H. Beck, Warszawa 2007, s. 5. 
nych naleciałości - mógłby pełnić rolę swego rodzaju subsydiarnego źródła prawa, będąc „,...] zwornikiem systematyzującym prawo prywatne i określającym podstawowe instytucje prawne"41 (lecz niczym ponadto).

Gruntowna zmiana nie byłaby procesem nagłym, lecz podbudowanym właściwa „wielką mobilizację nauki prawa cywilnego" oraz reformą sądownictwa i zmianą modelu kształcenia. W tym kontekście obecnie podejmowane działania kodyfikacyjne są wysiłkiem, który użyteczny byłby tylko o tyle, o ile rzeczywiście stanowiłby etap przejściowy, pozwalający poprzez kodeks cywilny wyjść poza kodeks cywilny. Nadrzędnym celem winno być natomiast obalenie prawotwórczego monopolu prawodawcy oraz zmiana paradygmatu.

Aby stało się to możliwe, sędziowie musieliby upomnieć się o przywrócenie należytej pozycji judykatury w trójpodziale władzy. Równolegle należałoby podjać wysiłki na rzecz stworzenia optymalnego modelu kształcenia sędziów. Tu zmiany winny być kompleksowe - od studiów (elitarność, a nie masowość), przez reformę aplikacji i egzaminów państwowych, po stworzenie komfortowych warunków pracy w judykaturze (liczny personel pomocniczy, wzrost wynagrodzenia, mniejszy przydział spraw). Powstałaby wówczas szansa, by sędziowie wyzbyli się - wyrabianego obecnie przez nadzór - nawyku formalizmu. Dzięki temu dominantą podejmowanych rozstrzygnięć przestałoby być - dziś nagminne - zręczne przywoływanie kazuistycznie zredagowanych przepisów. W naturalny sposób pojawiłoby się za to miejsce na wszechstronna (także pozasystemowa) argumentację, mającą na celu przekonanie stron do zasadności wydanego orzeczenia.

Od cywilistów należałoby wymagać skierowania energii (trwonionej obecnie na podejmowanie prób kodyfikacyjnych) na proces zawiązywania ogólnopolskiej współpracy nad wnikliwym opracowaniem zasad prawa prywatnego, z jednoczesnym ich osadzeniem w kontekście historycznym i porównawczym. Konieczne byłoby stworzenie stałych niehermetycznych grup badawczych, od których należałoby wymagać nie kolejnych projektów, lecz rzetelności, niezmąconej presją czasu. Do osiagnięcia tego celu wykorzystać należałoby prócz środków własnych wydziałów - także system grantowy, przez co w końcu otworzyłaby się szansa na zawiązanie trwałych relacji pomiędzy ośrodkami naukowymi oraz podjęcie współpracy z badaczami reprezentującymi inne dyscypliny. Zmiana modelu dałaby szansę polskiej cywilistyce na powrót na należne jej miejsce w europejskiej nauce prawa prywatnego. Podjęcie rozwiązań odważnych wzbudziłoby żywe zainteresowanie przedstawicieli obcych systemów prawnych, które przecież także - w mniejszym lub większym stopniu borykają się z podobnymi problemami.

Nie wiemy, co przyniesie przyszłość. Być może znów podjęte zostaną próby urzeczywistnienia idei wspólnego prawa cywilnego dla Europy. O ile wcześniej rola rodzimej cywilistyki sprowadzała się zasadniczo do biernej obserwacji ścierających się idei, o tyle teraz polscy prawnicy mogliby być gotowi na merytoryczną dyskusję o wartościach, na jakich chcielibyśmy budować wspólne

${ }^{41}$ Z. Radwański, Kodyfikacja polskiego prawa cywilnego na tle harmonizacji prawa prywatnego Unii Europejskiej, w: W. Czapliński (red.), Prawo w XXI wieku. Księga pamiatkowa 50-lecia INP PAN, Scholar, Warszawa 2006, s. 691. 
prawo. Do tego jednak potrzeba zmian. Dziś natomiast warto postawić pytanie o powołanie współczesnych cywilistów: Czy są oni rzeczywiście rzecznikami rozwiązań dobrych i słusznych, czy już może bardziej adwokatami rzekomo racjonalnego prawodawcy?

mgr Jan Andrzejewski

Uniwersytet im. Adama Mickiewicza w Poznaniu

j.and@amu.edu.pl

\section{IS THE NEW CODIFICATION OF CIVIL LAW REALLY NECESSARY IN THE TIMES OF THE CRISIS OF LAW?}

Sum mary

This paper reflects on the justified reasons that underlay the continuation of the works on a new version of the Polish Civil Code. The author proposes a departure from the current method of the regulation of the civil code, which seems to be now exhausted and offering no hope of improvement. He justifies his views by indicating the necessity to face and challenge the imminent crises that affect the legislature (de-codification, hasty and not well thought over decisions of amendments, or departure from the law-making model based on negotiations) but also the science of civil law (the crisis of universities - the teaching focused on the needs and expectations of a mass student group and the dogmatic-views of the researchers) and the judicature in which the judges are brought down to the position of 'higher level clerks' working in work overloaded courtrooms. The paper identifies the insufficiencies of the current reflection on private law, and to illustrate this, two examples are offered: the recent and doubtful amendments to the Civil Code (to which a new provision of Article $72 \S 2$ was added) and the insufficient doctrinal reflection given to exploitation (Article 388 of the Civil Code). In conclusion the author proposes a departure from the current system in favour of a system whose roots are based on legal principles defined and precised by legal science and judicial decisions 
Copyright of Journal of Law, Economics and Sociology is the property of Faculty of Law and Administration of Adam Mickiewicz University in Poznan and its content may not be copied or emailed to multiple sites or posted to a listserv without the copyright holder's express written permission. However, users may print, download, or email articles for individual use.

Właścicielem praw autorskich do „Ruchu Prawniczego, Ekonomicznego i Socjologicznego” jest Wydział Prawa i Administracji Uniwersytetu im. Adama Mickiewicza w Poznaniu. Zawartość czasopisma nie może być kopiowana, przesyłana do innych stron internetowych bądź zamieszczana na blogach bez pisemnej zgody wydawcy. Niemniej artykuły można drukować, kopiować lub przesyłać w formie elektronicznej na własny użytek. 